\title{
Performance of Sporobolus spicatus ecotypes, UAE native grass, under various salinity levels
}

\author{
Muhammad Zamin* and Abdul Mateen Khattak \\ Department of Horticulture, Faculty of Crop Production Sciences, The University of Agriculture, Peshawar-Pakistan \\ *Corresponding author's email: zaminhort@yahoo.com \\ Citation \\ Muhammad Zamin and Abdul Mateen Khattak. Performance of Sporobolus spicatus ecotypes, UAE native grass, \\ under various salinity levels . Pure and Applied Biology. Vol. 6, Issue 2, pp595-604. \\ http://dx.doi.org/10.19045/bspab.2017.60061
}

\begin{tabular}{llll}
\hline \hline Received: 27/01/2017 & Revised: 05/04/2017 & Accepted: 14/04/2017 & Online First: 19/04/2017 \\
\hline \hline
\end{tabular}

\section{Abstract}

Various ecotypes of Sporobolus spicatus were screened for their suitability as turf grass in public landscape. The experiment was conducted during the year 2014, where 50 ecotypes of Sporobolus spicatus were tested against different salinity levels, i.e. 0, 15, 30, 45, 60 and $75 \mathrm{dSm}^{-1}$. Significant differences were recorded for different agronomic parameters such as green cover, canopy stiffness and salinity of leaf rinseates. Many of the ecotypes supplied with saline water up to $30 \mathrm{dSm}^{-1}$ gave better performance in terms of green cover, canopy stiffness and salinity of leaf rinseates. However, beyond this level, the grasses' green cover decreased and most of the ecotypes ceased to grow, though some of the ecotypes survived even at salinity levels of $75 \mathrm{dSm}^{-1}$. Most of the ecotypes were found better than Paspalum vaginatum, the prevailing commercial turf grass in UAE (used as control in this instance). Ecotypes ARDS1, AQDS1, SAADS1, RS2 and RADS2 performed well at high salt levels and maintained major quality attributes such as green cover and canopy stiffness up to acceptable level. Based on their performance, these ecotypes can be recommended for turf use in public landscape under saline conditions.

Keywords: Halophytes; Turf; Saline water; Landscaping

\section{Introduction}

Turf grasses are among the most important plant groups that are used extensively in the landscape of new cities, coastal resorts and touristic villages. Some of these communities are developed in desert areas where irrigation water scarcity is common and the primary source of irrigation water is either wells or desalination units, which provide relatively saline water [1].

The increasing trends in desertification of arable lands necessitate the use of low quality, saline water for irrigation, especially in arid regions facing serious water shortage. However, using this saline water puts further stress on plants that are already under stressful conditions. Thus, the only option is to search for salt tolerant grass species that can survive under such stressful conditions. Since the indigenous grasses are already growing under such conditions and are adapted to these stresses, they are the most suitable under these harsh environmental conditions. If stress tolerant genotypes of 
these indigenous plants are identified and used, there will be significant savings in landscape maintenance in terms of inputs, such as water, fertilizers and agrochemicals thus resulting into sustainable and economical landscaping [2]. Some native ecotypes have quality indices, which are better than commercial cultivars [3]. Therefore, these salt tolerant plants need to be identified and introduced in public landscape to develop a sustainable ecosystem and ensure reasonable productivity [4]. Sporobolus spicatus is a native species of United Arab Emirates, which is suitable for the rehabilitation of degraded salt-affected habitats [5]. United Arab Emirates has vast brackish (highly saline) ground water resources, which cannot be used for conventional crops. However, it can be used to develop biosaline agriculture and urban landscape industries. Sporobolus spicatus is normally found in coastal sabhkas, with soil salinities above sea water (up to $100 \mathrm{dSm}^{-1}$ ); therefore, direct sea water can be used for irrigation. Sabkha is an Arabic word used for salty flat area normally occurring between desert and ocean [6, 7]. Using halophytes (salt loving plants) in salty water agriculture will save valuable fresh water for domestic use [8] which will lead towards sustainability.

Therefore, the research project was aimed to find out the suitability of Sporobolus spicatus ecotypes, collected from various areas of the United Arab Emirates, for turf purpose.

\section{Materials and methods}

The experiment was conducted in Al Khatim Farm of the UAE University during the year 2014. The experimental plot for salinity tests was located along Abu Dhabi-Al Ain highway around 70KM away from $\mathrm{Abu}$ Dhabi City (Google Coordinates $\left.24^{\circ} 12^{\prime} 2.19^{\prime \prime} \mathrm{N}, \quad 55^{\circ} 1{ }^{\prime} 32.69^{\prime \prime} \mathrm{E}\right) . \quad$ In this experiment 50 ecotypes of Sporobolus spicatus were studied for their salt tolerance.
Paspalum vaginatum was used as control during the experiment for the ecotypes evaluation.

The experiment was laid out in RCBD with two factors and 4 replications.

The following two factors were investigated; Factor 1: Salinity (5 levels, i.e. 15, 30, 45 60, and $75 \mathrm{dSm}^{-1}+$ tape water as control).

Factor 2: Sporobolus spicatus 50 ecotypes + Paspalum vaginatum as control.

The five salinity $(\mathrm{NaCl})$ levels along with control (tap water) were applied to all the ecotypes using drip irrigation system using the same concept of Uddin et al. [9] for various grasses. They used the maximum salinity level of $72 \mathrm{dSm}^{-1}$. The highest salinity levels were selected as per the recommendation by Lee et al. [10]. They studied different growth parameters at 0 to $35 \mathrm{dSm}^{-1}$ but recommended further salt tolerance evaluation of halophytic turf grasses at higher salinity levels.

\section{Irrigation system}

Drip irrigation system with a single emitter per pot was designed, which was connected to 500 liter water tank via a noncorroded/salt resistant manually operated pumps. Irrigation water was applied at $200 \mathrm{ml}$ per pot twice a day. The pots were flushed with fresh water once a week to avoid salt accumulation. For each salinity level there was a separate tank with separate irrigation network. The water requirement of grass in a pot was calculated from Abu Dhabi Municipality irrigation specifications [11]. The irrigation system was operated manually on daily basis.

\section{Preparation of salt solution}

The water tank was half-filled with water and then salt $(99 \% \mathrm{NaCl})$ was added gradually and electrical conductivity (EC) checked with the help of EC meter until it reached the required salinity level. The recommended fertilizer dose was also integrated with saline water for each salinity treatment. 


\section{Planting procedure}

50 ecotypes of Sporobolus spicatus grass were grown in $10 \mathrm{~cm}$ plastic pots using standard planting medium, a mixture of sand and compost (9:1) using the same concept of Uddin et al. [9] and maintained till establishment. After the establishment, the pots were placed in shade house with $40 \%$ shade material in May 2014 with $40^{\circ} \mathrm{C}$ average day temperature and variable relative humidity. The shade was provided to reduce water requirement and keep the grass from harsh wind and other environmental impacts.

\section{Acclimatization period}

After the fresh water application, salt $(\mathrm{NaCl})$ was added to the water tank with an increment of $5 \mathrm{dSm}^{-1}$ every three days till reaching the required salinity level. Following is the detail of days taken to reach the respective required salinity level;

Treatment $6\left(75 \mathrm{dSm}^{-1}\right)=45$ days

Treatment $5\left(60 \mathrm{dSm}^{-1}\right)=36$ days

Treatment $4\left(45 \mathrm{dSm}^{-1}\right)=27$ days

Treatment $3\left(30 \mathrm{dSm}^{-1}\right)=18$ days

Treatment $2\left(15 \mathrm{dSm}^{-1}\right)=9$ days

Treatment 1 (tape water/control)

Upon the completion of acclimatization period, the grasses were clipped at $3 \mathrm{~cm}$ height and discarded without collecting any data. Then they were given the relevant salinity treatments up to two weeks. At the end of two weeks' period, data were recorded on the clipped grasses for the parameters mentioned below.

\section{Parameters studied}

The following variables were studied during the experiment to observe responses of different ecotypes to the varying salinity levels

1. Green cover (1-10)

2. Canopy stiffness (1-10 how hard or soft the grass feels?)

3. Salinity of leaf rinseate $\left(\mathrm{mg} \mathrm{l}^{-1}\right)$

The response of different ecotypes of turf grass was studied and shown against each treatment for all variables. All the possible interactions were recorded as well. The data were analysed via Statistix 8.1 software applying the analysis of variance (ANOVA) technique [12]. ANOVA was used to see the variance among the means. In case the differences were significant, the means were further subjected to Tukey's test to observe the differences between individual means [13]. Though the data were analysed using ANOVA Tukey's test, the means of all the parameters were further subjected to cluster analysis (CA) due to large number of treatments (51) in the experiment. The incorporation CA facilitated to group ecotypes and understand the results in better way. For this purpose, Statistica version 7 (Dell Inc. USA) software was used. Based on the above data the grass ecotypes with high salt tolerance were selected and recommended for further multiplication.

\section{Results and discussion}

As mentioned above, various growth related variables were studied during the experiment such as green cover, canopy stiffness and salinity of leaf rinseates as below.

\section{Cluster analysis}

At a linkage distance of 5.3, all the ecotypes were divided into 3 clusters. Cluster 1 consisted of 14 ecotypes, cluster 2 had 16 and cluster 3 contained 21 ecotypes as shown in Figure 1. As far as the means data of each cluster is concerned, cluster 1 contained ecotypes which produced all the characters with highest means value such as green cover (6.32), canopy stiffness (5.86) and leaf rinseates salinity $\left(0.40 \mathrm{mg}^{-1}\right)$ (Table 1). Although, the lowest canopy stiffness is preferred which is included in cluster 3 with lowest value of 4.28. Ali et al. [14] extracted 4 clusters in 70 wheat genotypes and according to their findings cluster 2 had the most important characters for screening. 
Cluster Diagram of 51 Ecotypes in

Salinity Experiment ( 0 to $75 \mathrm{dsm}$ ) - SS Species

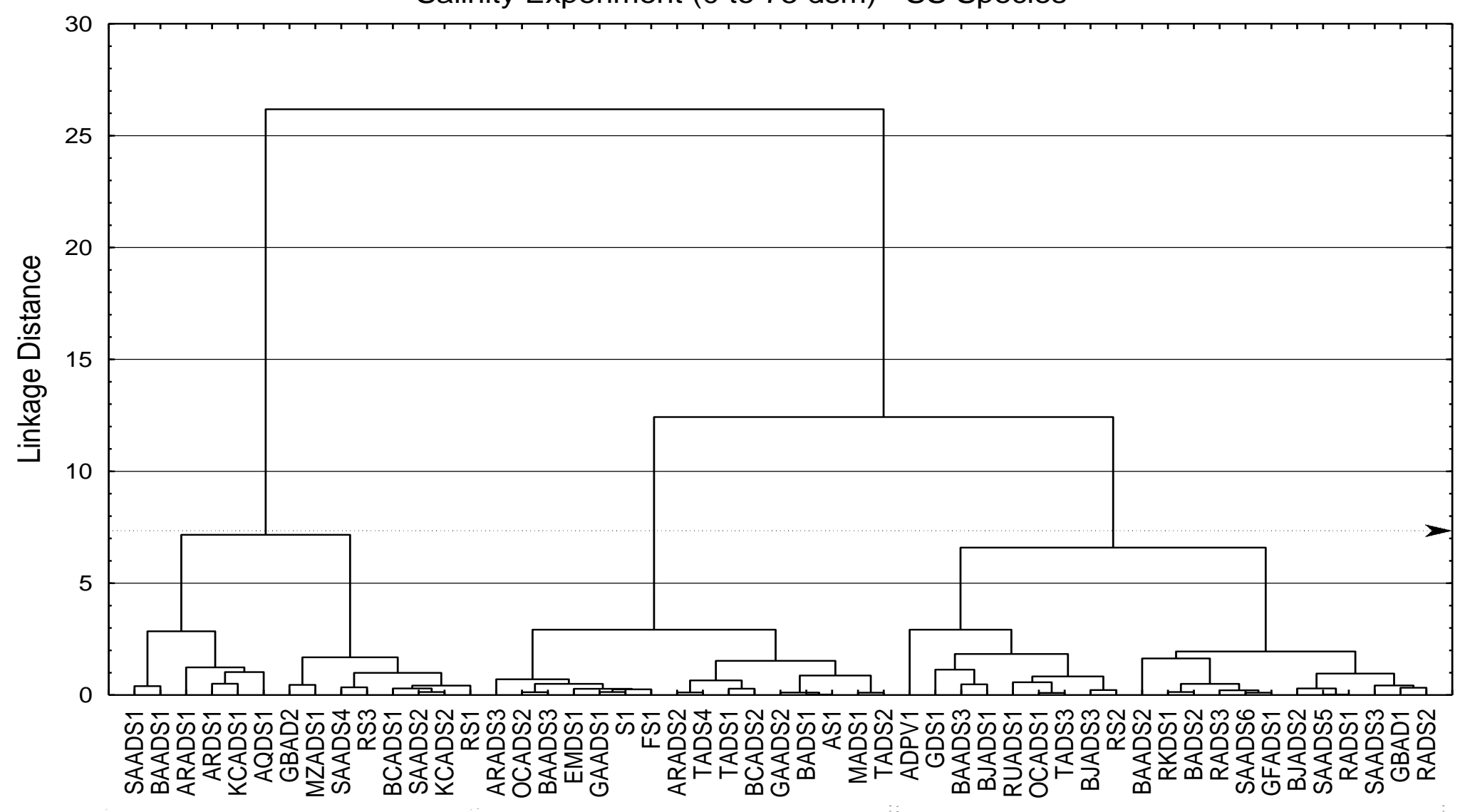

Figure 1. Dendrogram for 50 Sporobolus spicatus ecotypes and Paspalum (ADPV1; as control) based different agronomic characters 
Table 1. Cluster means and standard deviations for various parameters for different Sporobolus spicatus ecotypes (50) and Paspalum (ADPV1; control)

\begin{tabular}{|c|c|c|c|}
\hline Parameter & Cluster I (14 ecotypes) & Cluster II (16 ecotypes) & Cluster III (21 ecotypes) \\
\hline Green cover & $6.32 \pm 0.52^{*}$ & $5.67 \pm 0.38$ & $5.67 \pm 0.40$ \\
\hline Canopy stiffness & $5.86 \pm 0.69$ & $4.37 \pm 0.61$ & $4.28 \pm 0.75$ \\
\hline Leaf rinseates salinity & $0.40 \pm 0.08$ & $0.25 \pm 0.06$ & $0.24 \pm 0.05$ \\
\hline
\end{tabular}

${ }^{*}$ Standard Deviation

\section{Green cover (1-10)}

Different salinity levels had a significant $(\mathrm{P} \leq 0.001)$ effect on the green cover of Sporobolus spicatus ecotypes. The means data of salinity (Table 2) shows that the highest green cover was recorded in ecotypes supplied with tape water while at $15 \mathrm{dS}^{-1}$ salinity, green cover was reduced to 8.5 , followed by 8.28 and 7 at salinity levels of 30 and $45 \mathrm{dS}^{-1}$ respectively. Minimum (0.2) ground cover was observed at $75 \mathrm{dS}^{-1}$ followed by 1.2 at $60 \mathrm{dS}^{-1}$. Regarding performance of ecotypes in terms of green cover, varying performance of different ecotypes was observed as shown in Table 2 . To further evaluate the comparison of the ecotypes, the data were subjected to cluster analysis for making groups of ecotypes based on similarities in performance. The cluster analysis extracted 3 clusters. Among these cluster 1 had maximum (6.38) means for green followed by cluster 2 and 3 (5.67). The best performing ecotypes in cluster 1 were ARDS1 (7.23), AQDS1 (6.96) and SAADS1 (6.85). Table 2 Shows that most of the ecotypes had resistance to salinity up to $45 \mathrm{dSm}^{-1}$, which is the salt level of sea water.
Green cover is the main feature of any turf grass, thus more the grass density the higher will be its quality and aesthetic value. Since, most ecotypes survived at salinity of sea level, therefore these ecotypes have advantage over exotic cultivars of turf grasses. The results are matching with the findings of Shahba [15] who carried out similar experiments on Bermuda grass cultivars for various salinity levels. Chen et al. [16] also found the significant effect of salinity on green cover of four salt tolerant grasses confirming these findings. As we see in Table 2 the salinity effect from 15 to 45 $\mathrm{dSm}^{-1}$ was less but immediate drop of green cover occurred at $60 \mathrm{dSm}^{-1}$. Similar results were also reported by Uddin et al. [9] who found significantly different response of various grass ecotypes against salinity levels. These results are in line with the findings of Naz et al. [17], who also found significantly different ecotypes in Sporobolus species in terms of their response to varying salinity levels. Marcum and Pessarakli [18] also found a wide range of salinity tolerance in various cultivars of grass.

Table 2. Effect of different salinity levels (0-75 $\left.\mathrm{dSm}^{-1}\right)$ on green cover (1-10) and canopy stiffness (1-10) of 50 Sporobolus spicatus ecotypes and Paspalum (ADPV1; as control)

\begin{tabular}{|c|c|c|c|c|c|c|c|c|c|c|c|c|c|c|}
\hline \multirow[t]{2}{*}{ Ecotypes } & \multicolumn{7}{|c|}{$\begin{array}{c}\text { Green Cover }(1-10) \\
\text { Salinity Levels }\left(\mathrm{dSm}^{-1}\right)\end{array}$} & \multicolumn{7}{|c|}{$\begin{array}{l}\text { Canopy Stiffness }(1-10) \\
\text { Salinity Levels }\left(\mathrm{dSm}^{-1}\right)\end{array}$} \\
\hline & 0 & 15 & 30 & 45 & 60 & 75 & Means & 0 & 15 & 30 & 45 & 60 & 75 & Means \\
\hline RADS2 & 9.75 & 9.75 & 8.25 & 7.50 & 0.00 & 0.00 & 5.88 & 5.50 & 1.25 & 7.25 & 5.75 & 0.00 & 0.00 & 3.29 \\
\hline RS1 & 10.00 & 9.00 & 9.00 & 6.25 & 5.25 & 0.00 & 6.58 & 5.75 & 1.75 & 6.25 & 4.13 & 5.25 & 0.00 & 3.85 \\
\hline RS2 & 10.00 & 9.00 & 7.50 & 7.13 & 0.00 & 0.00 & 5.60 & 6.00 & 2.00 & 6.50 & 3.88 & 0.00 & 0.00 & 3.06 \\
\hline TADS2 & 10.00 & 7.50 & 8.50 & 5.75 & 2.50 & 0.00 & 5.71 & 5.75 & 2.50 & 5.50 & 3.75 & 5.75 & 0.00 & 3.88 \\
\hline TADS3 & 10.00 & 9.25 & 8.50 & 8.00 & 0.00 & 0.00 & 5.96 & 6.00 & 6.50 & 5.50 & 6.25 & 0.00 & 0.00 & 4.04 \\
\hline FS1 & 10.00 & 9.00 & 7.50 & 7.13 & 0.00 & 0.00 & 5.60 & 6.25 & 7.00 & 6.50 & 7.38 & 0.00 & 0.00 & 4.52 \\
\hline S1 & 9.50 & 8.50 & 7.25 & 6.50 & 0.00 & 0.00 & 5.29 & 6.00 & 6.00 & 7.00 & 6.28 & 0.00 & 0.00 & 4.21 \\
\hline EMDS1 & 9.75 & 7.00 & 8.50 & 5.75 & 0.00 & 0.00 & 5.17 & 1.50 & 7.00 & 5.50 & 7.25 & 0.00 & 0.00 & 3.54 \\
\hline
\end{tabular}




\begin{tabular}{|c|c|c|c|c|c|c|c|c|c|c|c|c|c|c|}
\hline AS1 & 50 & .75 & 50 & .75 & 0.00 & 0.00 & 5.4 & 6.00 & 7.25 & 6.25 & 8.00 & 0.0 & 0.0 & 4.58 \\
\hline RUADS1 & .00 & 50 & 50 & 6.38 & 0.00 & 0.00 & 5.90 & 6.25 & 6.00 & 5.00 & 7.00 & 0.00 & , & 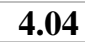 \\
\hline GA & 00 & 25 & 25 & 25 & .00 & .0 & 5 & 5 & 5.75 & 6.00 & 6.38 & 0 & & \\
\hline GFA & 15 & 8.00 & 0 & 38 & 00 & 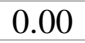 & 5.44 & 00 & 6.00 & 6.25 & .00 & & & 101 \\
\hline BAI & .00 & & & & 0.00 & & & & & & & & & \\
\hline BA & & 75 & 50 & 88 & 00 & & & & 00 & & .25 & & & \\
\hline OCADS1 & 75 & 00 & 25 & 00 & .00 & & & & 6.50 & 6.75 & 6.50 & & & 22 \\
\hline RAD & 75 & 25 & 25 & 38 & 0.00 & 0.0 & 5.7 & 5 & 6.00 & 5.00 & 7.00 & 00 & & .04 \\
\hline RAD & 75 & 25 & 50 & 50 & .00 & ( & 48 & & 6.75 & 6.50 & 7.88 & 00 & & .48 \\
\hline AQD & 00 & 25 & 50 & 7.25 & .50 & & 6 & & 6.00 & 4.50 & 7.25 & 00 & & 6.15 \\
\hline RS & & 15. & I & 6 & - & & & & & 5.50 & 50 & & & \\
\hline KCA & & 15 & 75 & 00 & 75 & & & & 0.00 & 5.25 & 7.50 & & & \\
\hline KCA & & 50 & 25 & 75 & .00 & & & 5 & 5.25 & 4.75 & 6.75 & & & \\
\hline RKI & & 00 & 50 & 00 & .00 & & & & 2.50 & 6.50 & 4.63 & 00 & & 35 \\
\hline MAI & & 75 & 25 & 75 & 150 & & & & 6.75 & 5.25 & 7.75 & & & .56 \\
\hline & & & & & & & & & & 6.25 & 88 & & & 69 \\
\hline & & & & & 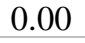 & & & & & & 50 & & & 0 \\
\hline & & & & 6 & 3 & & & & & 25 & 7.25 & & & \\
\hline BJ & & $\pi$ & & 6 & .5 & & & & 7.00 & 6.00 & 7.50 & & & 5.77 \\
\hline BJ & & 7 & & 6 & 0.0 & & & & 6.50 & 5.75 & 7.13 & & & .15 \\
\hline & & & & & & & & & & 6.25 & 88 & & & \\
\hline & & & & & & & & & & 00 & 25 & & & \\
\hline & & & & & & & & & & & 50 & & & 5.72 \\
\hline & & & & 5 & 1 & & & & & 6.2 & .00 & & & \\
\hline & & & & 8 & .0 & & & & 5. & 6.00 & 6.00 & & & 3.88 \\
\hline & & & & & 0 & & & & & 3.75 & 50 & & & 3.71 \\
\hline & & & & & & & & & & 3.50 & 6.00 & & & 15 \\
\hline & & & & & & & & & & 0 & 25 & & & 3.63 \\
\hline & & & & & & & & & & & 75 & & & \\
\hline & & & & & & & & & & & 6.88 & & & \\
\hline & & & & 5 & & & & & 6.50 & 6.25 & 7.50 & J & & 5.54 \\
\hline & & & & & & & & & & 6 & 6.75 & & & 5.35 \\
\hline & & & & & & & & & & & & & & 4.85 \\
\hline & & & & & & & & & & 25 & 50 & & & .42 \\
\hline & & & & & & & & & & & 75 & & & \\
\hline & & & & & & & & & & & 6.88 & & & \\
\hline & & & & & & & & & 6. & 6.50 & 6.00 & 0 & & \\
\hline & & & & & & & & & & & 6.63 & & & \\
\hline & & & & & & & & & J & 0 & 75 & & & \\
\hline & & 8.7 & & 1.1 & & & & & 5.75 & 6.50 & 6.38 & 13 & & 5.38 \\
\hline & & & & & & & & & & & .25 & & & \\
\hline & & & & & & & & & & & 03 & & & \\
\hline & & & & & & & & & & & 4.25 & & & \\
\hline & & 8.50 & 8.28 & 7.00 & 1.20 & 0.2 & & 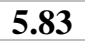 & 5.68 & 5.85 & 6.58 & 3.39 & 1. & 171 \\
\hline$T u$ & \multicolumn{7}{|c|}{$\begin{array}{r}\text { Salinity Levels at } P \leq 0 \\
\text { Ecotypes at } P \leq 0.00\end{array}$} & \multicolumn{7}{|c|}{$\begin{array}{l}2260 \\
86\end{array}$} \\
\hline
\end{tabular}

Note: In case the difference between two means is greater than Tukey values there will be significant difference at $\mathrm{P} \leq 0.001$

\section{Canopy stiffness (1-10)}

Canopy stiffness of Sporobolus spicatus ecotypes was significantly $(\mathrm{P} \leq 0.001)$ affected by different salt concentrations (Table 2). According to the means data of salinity levels (Table 2), it is clear that the highest (6.58) canopy stiffness was found at $45 \mathrm{dSm}^{-1}$ followed by $30 \mathrm{dSm}^{-1}$ (5.85) which is at par with canopy stiffness at $15 \mathrm{dSm}^{-1}$ and $0 \mathrm{dSm}^{-1}$ salinity levels with stiffness values of 5.68 and 5.83 respectively. The lowest (1.12) canopy stiffness was recorded 
at $75 \mathrm{dSm}^{-1}$ followed by $60 \mathrm{dSm}^{-1}$ (3.39). The differences among the ecotypes were also significant. For Further details, cluster analysis was performed to obtain groups of ecotypes based on their similarities. According to Figure 1, the highest (5.86) canopy stiffness was seen for cluster 1, followed by cluster 2 (4.37), while the lowest value was provided by cluster 3 (4.28). The top 3 ecotypes in terms of canopy stiffness having minimum means were RS2 (3.06), RADS2 (3.29) and RKDS1 (3.35). The canopy stiffness/softness is the main quality character of a turf grass. Hu et al. [19] also found similar trend of decreasing grass quality by increasing salt stress. The results are in line with the findings of Tuttolomondo et al. [20] who also found significant variations in the response of various native ecotypes. Mintenko and Smith [21] reported that 5 out of 10 is an acceptable quality rating for turf grass. The variations and diversity found in ecotypes in terms of canopy stiffness could be used in future breeding program as stated by [22] and Romani et al. [23], who identified similar better performing ecotypes. Canopy stiffness is due to the sharp pointed leaf which is further increased because of increased salinity level. Higher salinity levels coupled with leaf curling, increased the stiffness thus reducing turf quality. Though they performed well, most of the ecotypes were lesser in softness as compared to Paspalum vaginatum (ADPV1), which is locally grown in urban landscape. Thus, Sporobolus spicatus are less suitable for lawns and playgrounds compared to Paspalum in terms of canopy stiffness. However, these ecotypes can be used as ground covers for avenue plantation, such as centre medians or roads sides.

\section{Salinity of leaf rinseates $\left(\mathrm{mg} \mathrm{l}^{-1}\right)$}

The data regarding leaf rinseates in Table 3 shows that the leaf rinseates of Sporobolus spicatus ecotypes was significantly
$(\mathrm{P} \leq 0.001)$ affected by various salinity levels. As indicated in Table 3, maximum $(0.49 \mathrm{mg}$ $1^{-1}$ ) salinity in leaves rinseates was found at $45 \mathrm{dSm}^{-1}$ followed by $0.43 \mathrm{mg} \mathrm{l}^{-1}$ at $30 \mathrm{dSm}^{-1}$ and $0.37 \mathrm{mg} \mathrm{l}^{-1}$ at $15 \mathrm{dSm}^{-1}$, while minimum $\left(0.13 \mathrm{mgl}^{-1}\right)$ leaves rinseates salinity was recorded at $75 \mathrm{dSm}^{-1}$. To further elaborate the means comparison of ecotypes, the data were subjected to cluster analysis. As shown in Table 1 , the highest $\left(0.40 \mathrm{mg}^{-1}\right)$ means value of leaf rinseates salinity was found in cluster 1 , followed by cluster $2\left(0.25 \mathrm{mg} \mathrm{l}^{-1}\right)$, while the lowest $\left(0.24 \mathrm{mg}^{-1}\right)$ salinity in leaves rinseates was observed in cluster 3 . As far as the performance of individual ecotypes is concerned, the top three ecotypes were included in cluster 1, i.e. ARDS1 $\left(0.52 \mathrm{mg} \mathrm{l}^{-1}\right)$ followed by SAADS1 $(0.51 \mathrm{mg}$ $\left.1^{-1}\right)$ and ARADS1 $\left(0.49 \mathrm{mg}^{-1}\right)$. The lowest $\left(0.16 \mathrm{mg} \mathrm{l}^{-1}\right)$ concentration of leaf rinseates was observed in Paspalum vaginatum (ADPV1), which shows that the native grass ecotypes performance was far better than exotic grass (Paspalum vaginatum).

The concentration of salts in leaf rinseates indicates the salt glands activity of halophytes. Excretion of salts through leaves is one of the adaptation strategies in these grasses as reported by Barhoumi et al. [24] who found no serious damages occurring at higher salt concentrations in irrigation water. The same mechanism has been defined by Rumman [25] as well. These results are confirmed by Gulzar [26] who found that increasing salinity treatment lead to increased salts concentration in leaves. All the ecotypes showed high rate of salt exclusions upon increasing the salinity levels, which is the main feature and strategy of halophytes. These results are in line with Marcum and Pessarakli [18] findings, who carried out similar studies on various cultivars of Bermuda grass. They found that salinity tolerance was positively correlated with leaf salt gland $\mathrm{Na}^{+}$excretion rate. This indicates that salinity tolerance in grasses is 
associated with saline ion exclusion and leaf salt gland excretion efficiency. The salinity tolerance at higher salt levels of 60 and $75 \mathrm{dSm}^{-1}$ is related to the rate of salt gland activities in leaves and is indicated by salt concentration in leaf rinseates, as stated by
Marcum et al. [27]. Similar results were also found by Barhoumi et al. [28] on Aeluropus littoralis, a perennial halophyte. They found that sodium and chloride ion contents in shoots and roots increased with increase in salinity concentrations of irrigation water.

Table 3. Effect of different salinity levels $\left(0-75 \mathrm{dSm}^{-1}\right)$ on leaf rinseates salinity $\left(\mathrm{mgl}^{-1}\right)$ of 50 Sporobolus spicatus ecotypes and Paspalum (ADPV1; as control)

\begin{tabular}{|c|c|c|c|c|c|c|c|c|c|c|c|c|c|c|c|}
\hline \multirow{3}{*}{ Ecotypes } & \multirow{2}{*}{\multicolumn{7}{|c|}{$\frac{\text { Leaf rinseates salinity }\left(\mathrm{mg} \mathrm{l}^{-1}\right)}{\text { Salinity Levels }\left(\mathrm{dSm}^{-1}\right)}$}} & \multirow{3}{*}{ Ecotypes } & \multirow{2}{*}{\multicolumn{7}{|c|}{$\frac{\text { Leaf rinseates salinity }\left(\mathrm{mg} \mathrm{l}^{-1}\right)}{\text { Salinity Levels }\left(\mathrm{dSm}^{-1}\right)}$}} \\
\hline & & & & & & & & & & & & & & & \\
\hline & \multicolumn{7}{|c|}{75} & & $\mathbf{0}$ & 15 & 30 & 45 & 60 & 75 & Means \\
\hline RADS2 & 0.00 & 0.42 & 0.50 & 0.49 & 0.00 & 0.00 & 0.24 & BJADS3 & 0.00 & 0.36 & 0.45 & 0.51 & 0.65 & 0.00 & 0.33 \\
\hline RS1 & 0.00 & 0.39 & 0.42 & 0.48 & 0.66 & 0.00 & 0.32 & BJADS2 & 0.00 & 0.39 & 0.41 & 0.44 & 0.00 & 0.00 & 0.21 \\
\hline RS2 & 0.00 & 0.35 & 0.40 & 0.44 & 0.00 & 0.00 & 0.20 & ARADS1 & 0.00 & 0.35 & 0.41 & 0.45 & 0.65 & 1.07 & 0.49 \\
\hline TADS2 & 0.00 & 0.43 & 0.46 & 0.48 & 0.64 & 0.00 & 0.34 & BAADS1 & 0.00 & 0.35 & 0.41 & 0.44 & 0.66 & 0.90 & 0.46 \\
\hline TADS3 & 0.00 & 0.39 & 0.46 & 0.52 & 0.00 & 0.00 & 0.23 & BAADS2 & 0.00 & 0.39 & 0.40 & 0.51 & 0.00 & 0.00 & 0.22 \\
\hline FS1 & 0.00 & 0.38 & 0.46 & 0.49 & 0.00 & 0.00 & 0.22 & BAADS3 & 0.00 & 0.43 & 0.46 & 0.66 & 0.66 & 0.00 & 0.37 \\
\hline S1 & 0.00 & 0.40 & 0.45 & 0.46 & 0.00 & 0.00 & 0.22 & TADS4 & 0.00 & 0.40 & 0.45 & 0.48 & 0.00 & 0.00 & 0.22 \\
\hline EMDS1 & 0.00 & 0.39 & 0.46 & 0.48 & 0.00 & 0.00 & 0.22 & GAADS2 & 0.00 & 0.35 & 0.45 & 0.56 & 0.00 & 0.00 & 0.23 \\
\hline AS1 & 0.00 & 0.35 & 0.44 & 0.44 & 0.00 & 0.00 & 0.21 & MZADS1 & 0.00 & 0.35 & 0.46 & 0.68 & 0.66 & 0.69 & 0.47 \\
\hline RUADS1 & 0.00 & 0.38 & 0.39 & 0.45 & 0.00 & 0.00 & 0.20 & TADS1 & 0.00 & 0.39 & 0.43 & 0.48 & 0.00 & 0.00 & 0.22 \\
\hline GAADS1 & 0.00 & 0.39 & 0.42 & 0.47 & 0.00 & 0.00 & 0.21 & ARDS1 & 0.00 & 0.31 & 0.46 & 0.62 & 0.67 & 1.06 & 0.52 \\
\hline GFADS1 & 0.00 & 0.42 & 0.43 & 0.49 & 0.00 & 0.00 & 0.22 & GDS1 & 0.00 & 0.33 & 0.35 & 0.45 & 0.66 & 0.00 & 0.30 \\
\hline BADS2 & 0.00 & 0.43 & 0.44 & 0.48 & 0.00 & 0.00 & 0.23 & BAADS3 & 0.00 & 0.32 & 0.46 & 0.47 & 0.66 & 0.00 & 0.32 \\
\hline BADS1 & 0.00 & 0.35 & 0.40 & 0.49 & 0.00 & 0.00 & 0.21 & OCADS2 & 0.00 & 0.40 & 0.48 & 0.49 & 0.67 & 0.00 & 0.34 \\
\hline OCADS1 & 0.00 & 0.40 & 0.50 & 0.56 & 0.00 & 0.00 & 0.24 & ARADS3 & 0.00 & 0.34 & 0.37 & 0.49 & 0.67 & 0.00 & 0.31 \\
\hline RADS3 & 0.00 & 0.42 & 0.46 & 0.48 & 0.00 & 0.00 & 0.23 & SAADS6 & 0.00 & 0.32 & 0.40 & 0.48 & 0.00 & 0.00 & 0.20 \\
\hline RADS1 & 0.00 & 0.26 & 0.43 & 0.44 & 0.00 & 0.00 & 0.19 & GBAD1 & 0.00 & 0.32 & 0.39 & 0.46 & 0.00 & 0.00 & 0.19 \\
\hline AQDS1 & 0.00 & 0.37 & 0.40 & 0.43 & 0.51 & 0.64 & 0.39 & GBAD2 & 0.00 & 0.44 & 0.47 & 0.52 & 0.66 & 0.00 & 0.35 \\
\hline RS3 & 0.00 & 0.40 & 0.42 & 0.45 & 0.66 & 0.00 & $\mathbf{0 . 3 2}$ & SAADS1 & 0.00 & 0.33 & 0.44 & 0.46 & 0.66 & 1.15 & 0.51 \\
\hline KCADS2 & 0.00 & 0.37 & 0.40 & 0.44 & 0.66 & 0.00 & 0.31 & SAADS2 & 0.00 & 0.33 & 0.45 & 0.64 & 0.66 & 0.00 & 0.35 \\
\hline KCADS1 & 0.00 & 0.37 & 0.40 & 0.46 & 0.66 & 0.98 & 0.48 & SAADS3 & 0.00 & 0.35 & 0.45 & 0.55 & 0.62 & 0.00 & 0.33 \\
\hline RKDS1 & 0.00 & 0.35 & 0.46 & 0.50 & 0.00 & 0.00 & 0.22 & SAADS4 & 0.00 & 0.34 & 0.37 & 0.48 & 0.66 & 0.00 & 0.31 \\
\hline MADS1 & 0.00 & 0.38 & 0.48 & 0.61 & 0.67 & 0.00 & 0.36 & SAADS5 & 0.00 & 0.39 & 0.42 & 0.48 & 0.00 & 0.00 & 0.21 \\
\hline BCADS1 & 0.00 & 0.38 & 0.41 & 0.46 & 0.66 & 0.00 & 0.32 & ARADS2 & 0.00 & 0.33 & 0.40 & 0.48 & 0.00 & 0.00 & 0.20 \\
\hline BCADS2 & 0.00 & 0.41 & 0.41 & 0.44 & 0.00 & 0.00 & 0.21 & ADPV1 & 0.00 & 0.05 & 0.14 & 0.27 & 0.45 & 0.00 & 0.15 \\
\hline BJADS1 & 0.00 & 0.40 & 0.42 & 0.49 & 0.67 & 0.00 & 0.33 & Means & 0.00 & 0.37 & 0.43 & 0.49 & 0.32 & 0.13 & \\
\hline $\begin{array}{l}\text { Tukey's } \\
\text { values }\end{array}$ & & & & $=$ & 011 & .0117 & & & & & & & & & \\
\hline
\end{tabular}

Note: In case the difference between two means is greater than Tukey values there will be

significant difference at $\mathrm{P} \leq 0.001$

\section{Conclusions and recommendations}

From the experiment we concluded that the native grasses of UAE have potential to be used for turf purpose. The high salinity problem of UAE could be managed by utilization of the local grasses in public landscape, even the sea water could be used in worse conditions. Sporobolus spicatus ecotypes have more stiffness, therefore, they can be used as general ground covers in interchanges, roads centre-medians and public areas whereby greenery is the main objective. Further research work is recommended on native ecotypes of Sporobolus spicatus to find out their potential as donors of salt tolerant characteristic for improving other crops in breeding program. 


\section{Authors' contributions}

Conceived, designed and performed the experiments: M Zamin, Analyzed the data: M Zamin, Contributed reagents/ materials/ analysis tools: AM Khattak, Wrote the paper: M Zamin.

\section{Acknowledgements}

This paper is a part of my Thesis for the fulfilment of the Degree of Ph.D. I am thankful for the department of Horticulture, The University of Agriculture, Peshawar for the technical and supervisory support during my study, particularly Dr. Abdul Mateen Khattak. Thanks are extended to Department of Aridland Agriculture, Faculty of Food and Agriculture, UAE University for their support in providing me the opportunity of conducting research under their supervision.

\section{References}

1. Al-Shehhi AMH, Khan IA, Al-Said F, Deadman ML, Alkanjari S \& Ahmad T (2010). Evaluation of warm season turfgrass under different irrigation regimes in arid region. Notulae Scientia Biologicae 2(3): 30.

2. Pessarakli M (2015). Saltgrass, a potential future landscaping plant and a suitable species for desert regions: A review. International J Hort Sci Technol 2(1): $1-13$.

3. Viggiani R, Marchione V, Potenza G, Castronuovo D, Fascetti S \& Perniola M (2015). Agronomic behaviour of some Cynodon dactylon ecotypes for turfgrass use in the Mediterranean climate. Italian J Agronomy 10(1): 1-8.

4. Ashraf MY, Awan AR \& Mahmood K (2012). Rehabilitation of saline ecosystems through cultivation of salt tolerant plants. Pak J Bot 44: 69-75.

5. El-Keblawy A, Al-Sodany YM \& AlHadad FA (2009). Effects of time of seed maturation on dormancy and germination requirements of Sporobolus spicatus (Vahl) Kunth, a native desert grass of the United Arab
Emirates. Grassland Science 55(1): 1117.

6. Environment Agency Abu Dhabi (2009). Abu Dhabi Water Resources Master Plan. Ch. 2: Water availability and water use 33-51.

7. Murad AA, Al-Nuaimi H \& Al-Hammadi $M$ (2007). Comprehensive assessment of water resources in the United Arab Emirates (UAE). Water Resources Management 21(9): 1449-1463.

8. Khan MA \& Weber DJ (2006). Ecophysiology of High Salinity Tolerant Plants. Tasks for Vegetation Science. Springer Netherlands.

9. Uddin KAMAL, Juraimi AS, Ismail MR, Othman R \& Rahim AA (2009). Growth response of eight tropical turfgrass species to salinity. Afr $J$ Biotechnol 8(21).

10. Lee G, Duncan RR \& Carrow RN (2002). Initial selection of salt tolerant seashore paspalum ecotypes. USGA Turfgrass and Environmental Research Online 1(11): 1-9.

11. Municipality of Abu Dhabi City (2012). Irrigation System Operations and Maintenance. Volume 2A. Division 2. Section 2800 Part 4-B Watering requirement pp. 19.

12. Steel RGD, Torrie JH \& Dickey M (1980). A A biometrical approach. Principles and Procedures of Statistics 8-566.

13. Abdi H \& Williams LJ (2010). Tukey's honestly significant difference (HSD) test. Encyclopedia of Research Design. Thousand Oaks, CA: Sage 1-5.

14. Ali Y, Atta BM, Akhter J, Monneveux P \& Lateef Z (2008). Genetic variability, association and diversity studies in wheat (Triticum aestivum L.) germplasm. Pak J Bot 40(5): 20872097.

15. Shahba MA (2010). Interaction Effects of Salinity and Mowing on 
Performance and Physiology of Bermudagrass Cultivars. Crop Sci 50(6): 2620-2631.

16. Chen J, Yan J, Qian Y, Jiang Y, Zhang T \& Guo H (2009). Growth responses and ion regulation of four warm season turfgrasses to long-term salinity stress. Scientia Horticulturae 122(4): 620625.

17. Naz N, Hameed M \& Ashraf M (2010). Eco-Morphic Response to Salt Stress in two Halophytic Grasses from the Cholistan Desert, Pakistan. Pak J Bot 42(2): 1343-1351.

18. Marcum KB \& Pessarakli M (2006). Salinity Tolerance and Salt Gland Excretion Efficiency of Bermudagrass Turf Cultivars. Crop Sci 46(6): 25712574.

19. Hu L, Huang Z, Liu S \& Fu J (2012). Growth response and gene expression in antioxidant-related enzymes in two Bermuda grass genotypes differing in salt tolerance. J Am Society for Hort Sci 137(3): 134-143

20. Tuttolomondo T, La-Bella S, Licata M, Claudio L \& Sarno M (2007). Two years of studies into native Bermuda grass (Cynodon spp.) germplasm from Sicily (Italy) for the constitution of turf cultivars. In II International Conference on Turfgrass Science and Management for Sports Fields 783: 39-48.

21. Mintenko A \& Smith R (2001). Native grasses vary in salinity tolerance. turfgrass. Golf Course Management 55-59.

22. Dilaver Z (2013). Conservation of Natural Plants and Their Use in Landscape Architecture. Advances in Landscape Architecture 885-904.

23. Romani M, Piano E \& Pecetti L (2002). Collection and preliminary evaluation of native turfgrass accessions in Italy. Genet Resour Crop Evol 49(4): 341349.

24. Barhoumi Z, Djebali W, Abdelly C, Chaibi W \& Smaoui A (2008). Ultrastructure of Aeluropus littoralis leaf salt glands under $\mathrm{NaCl}$ stress. Protoplasma 233(3-4): 195-202.

25. Rumman GA (2012). Ecophysiology of Salinity tolerance in three halophytic turfgrasses. University of Western Australia.

26. Gulzar S, Khan MA \& Ungar IA (2003). Effects of salinity on growth, ionic content, and plant-water status of Aeluropus lagopoides. Commun. Soil Sci Plant Anal 34(11-12): 1657-1668.

27. Marcum K (2007). Relative Salinity Tolerance of Turfgrass Species and Cultivars. Handbook of Turfgrass Management and Physiology. Informa UK Limited 389-406.

28. Barhoumi Z, Djebali W, Smaoui A, Chaibi W \& Abdelly C (2007). Contribution of $\mathrm{NaCl}$ excretion to salt resistance of Aeluropus littoralis (Willd). Parl J Plant Physiol 164(7): 842-850. 